\title{
The Last Mountain Lake Game Preserve
}

\author{
by Mrs. J. M. Rutherford, Govan
}

On March 12, 1887, LieutenantGovernor Dewdney of the North West Territories wrote to Thomas White, Minister of the Interior, Ottawa, recommending that the islands at the north end of Long Lake (Last Mountain Lake) be reserved for a bird sanctuary. These islands were the favourite breeding grounds of almost all the different kinds of wildfowl in the "north," and the island shores were literally covered with eggs in the hatching season, he said. Encroaching settlement might soon threaten the wildlife of this area, for would-be settlers were attracted by rumours of the probable extension of the Long Lake railroad.

Previous to this, Professor Macoun had camped at the north end of Last Mountain Lake in 1879. Macoun was commissioned by the Government of Canada to report on the land, agricultural possibilities, and natural resources of the prairie west. Possibly his very enthusiastic report on the innumerable waterfowl here made the Ottawa government receptive to Governor Dewdney's suggestion.

In June, 1887, Dewdney was advised that the Governor-General in Council had been.pleased to set various lands aside under the Dominion Game Act for the protection of wildlife in this area. These lands were reserved from sale and settlement for breeding grounds for wildfowl. They were described in detail for the surveyors. They extended from Arlington Beach to the land at the north end of the lake, including most of the islands and parts of the shoreline. Altogether there were 2,50 acres of land. Correspondence on file shows that for several years after 1909, adjacent settlers made applications for portions of land in the reserve.

On July 26, 1921, there was a further federal Order-in-Council. This confirmed the acceptance of the IMigratory Birds Convention Act, originally signed between Canada and the United States in 1916 (and most recently confirmed in 1961), and its application to the breeding grounds in the vicinity of Last Mountain Lake in the Province of Saskatchewan, al- ready reserved by the order of June 8, 1887. Under the Migratory Birds Convention Act the Federal Government became responsible for the protection and management of migratory birds. In practice, however, wildlife is a joint project in which provincial and federal authorities cooperate-the return of the natural resources to the provinces in 1930 made this practice logical.

The 1921 Order-in-Council added islands not already included and specified small parts of the shoreline as well as all lands covered by Last Mountain Lake. The lands thus set aside and the entire water area of Last Mountain Lake were to be known as the "Last Mountain Lake Bird Sanctuary." The creation of the sanctuary within these boundaries had the full approval of Saskatchewan authorities. Within the sanctuary, shooting of game birds in the open season was permitted by the order in-council on all portions of Last Mountain Lake except the islands north of and including Pelican Island, Section 24, Township 27, Range 24, W. of the $2 \mathrm{nd}$.

Long before man divided this continent with international boundaries, migratory birds came north with the lengthening days to nest and rear their broods. Long hours of sunlight and cool nights provided lush vegetation and aquatic and animal life for rapid growth. When winter came and northern streams were frozen over and snow covered the land, each species of bird in its own time quietly slipped away to the warmer south.

There are some important differences between the spring and fall migration of birds. Spring flights follow a long period of winter feeding in preparation for migration, while fall migration comes after a busy summer of feeding young and often a seasonal moult. So, many birds tarry in the iall in resting areas like the north end of Last Mountain Lake where plentiful food supplies have been built up during the summer. There many of them grow new feathers to replace the summer moult.

The width of Last Mountain Lake varies from one mile to three miles, 
